http://kitaibelia.unideb.hu/

ISSN 2064-4507 (Online) • ISSN 1219-9672 (Print)

(C) 2015, Department of Botany, University of Debrecen, Hungary

20 (1): 143-149.; 2015

DOI: $10.17542 /$ kit.20.143

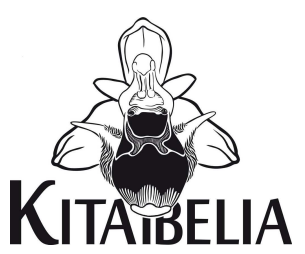

\title{
A hencidai Mondró-halom, a löszgyep-vegetáció őrzője
}

\author{
DEÁK Balázs ${ }^{1 *}$, TöRÖK Péter ${ }^{1,2}$, TóThMÉRÉSz Béla ${ }^{1,2}$ \& VALKó Orsolya ${ }^{1,2}$
}

(1) MTA-DE Biodiverzitás Kutatócsoport, H-4010, Debrecen, Pf.: 71.; *debalazs@gmail.com

(2) Debreceni Egyetem TTK Ökológiai Tanszék, H-4032, Debrecen, Egyetem tér 1.

\section{Mondró-halom kurgan (Hencida, East Hungary), a refugium of loess grassland vegetation}

\begin{abstract}
Fragments of the natural grassland vegetation are often preserved only in those areas which are inadequate for arable farming. In many cases kurgans hold the last remnants of dry grasslands in lowland areas, like the Great Hungarian Plain. They also have an essential role in preserving cultural and landscape values. Moreover, they harbour several rare plant and animal species. Our aim was to explore the vegetation of the Mondró-halom kurgan (Hencida, East Hungary). Altogether we found 74 vascular plant species in the loess grassland of the kurgan. Several rare species of the Bihari-sík region, such as Inula germanica, Ranunculus illyricus and Rosa gallica were also detected. The steep slopes of the kurgan with various micro-sites and exposures supported a speciesrich vegetation. Instead of its small area it harboured several forest steppic species and several steppic flora elements (Continental, Pontic-Mediterranean, Pontic, Pontic-Pannonic and Turanian).
\end{abstract}

Keywords: Bihari-sík, fragmentation, Inula germanica, barrow, burial mound

Összefoglalás - Intenzív művelésű mezőgazdasági területeken a természetes gyepvegetációnak gyakran csupán töredékei maradtak meg, rendszerint olyan helyeken, amelyek a mezőgazdasági művelésre alkalmatlannak bizonyultak. Alföldi körülmények között ilyen területek a kunhalmok, amelyek amellett, hogy kiemelkedő kulturális és tájképi értékekkel bírnak, számos ritka növény- és állatfajnak nyújtanak menedéket. Cikkünkben a hencidai Mondró-halom flóráját mutatjuk be. A halmot borító fajgazdag löszgyepben összesen 74 edényes növényfajt találtunk. A halmon számos, a Biharisíkon ritka növényfaj fordul elő, mint például az Inula germanica, Ranunculus illyricus és a Rosa gallica. A halom különböző kitettségű meredek lejtőin kialakult változatos mikro-élőhelyek hozzájárulnak a halom fajgazdagságának kialakításához és fenntartásához. Ennek is köszönhető, hogy a halmon az erdősztyeppi elemek mellett a legtöbb a Kárpát-medencében előforduló sztyeppei flóraelem-típus (kontinentális, pontusz-szubmediterrán, pontuszi, pontusz-pannon és turáni) megtalálható.

Kulcsszavak: Bihari-sík, fragmentáció, Inula germanica, kurgán, kunhalom

\section{Bevezetés és célkitűzés}

A szárazgyepek Eurázsiában kiemelt fontosságúak a biodiverzitás megőrzésében, mivel számos ritka és védett növény- és állatfajnak biztosítanak élőhelyet (DENGLER et al. 2014). Az intenzív művelésű mezőgazdasági terülteken a természetes gyep-fragmentumok csak olyan helyeken őrződhettek meg, amelyek valamilyen okból alkalmatlanok voltak a mezőgazdasági művelésre. Ez különösen igaz azokra az élőhelyekre, amelyek jó termőképességű termőhelyeken alakultak ki, mint például a zömében mezőségi talajokon jellemző löszgyepek 
(KELEMEN et al. 2010, TóTH \& HÜSE 2014). Ennek köszönhetően, különösen alföldi körülmények között, a löszgyepek állományainak jelentős része mezsgyéken és kunhalmokon maradt fent (Zólyomi 1969, CSATHó 2009, PENKSZA et al. 2011, CSATHó et al. 2015).

A kunhalmok keletkezése i.e. 4000-től a középkorig tehető, építésükben számos népcsoport vett részt (TóTH 2006). A kunhalmok elsősorban a fátlan, sztyeppei régióra jellemzőek. Elterjedésük nyugati határa a Kárpát-medencében található, keleti határa pedig a mongol sztyeppéken (SUDNIK-WóJCIKOWSKA \& MOYSIYENKO 2008). A kunhalmok funkciójukat tekintve eredetileg sírhalmok (kurgán) illetve lakóhalmok (tellek) voltak (TóTH 2006, BEDE 2014), a későbbiekben másodlagos funkciókat is betöltöttek: lehettek lakóhalmok, sírhalmok, őrhalmok, határhalmok és kultikus halmok is (DANI \& HoRVÁTH 2012). Funkciótól függetlenül jellemző rájuk, hogy olyan ősi, ember által létrehozott építmények, amelyek kiemelkedő tájképi, kulturális és természetvédelmi értékekkel bírnak (1996. évi LIII törvény a természet védelméről).

Viszonylag kis kiterjedésük ellenére (átlagos területük egy hektár alatt van) a kunhalmokon gyakran változatos növény- és állatvilág található. Ez leginkább annak köszönhető, hogy a kunhalmok meredek oldalait sok esetben nem tudták felszántani, és a különböző kitettségű meredek lejtőkön változatos mikro-élőhelyek és változatos mikroklíma alakul ki (VONA \& PENKSZA 2004, SUDNIK-WóJCIKOWSKA et al. 2011).

A magyarországi kunhalmokon leggyakrabban löszgyepi és szikes társulások őrződtek meg, a legtipikusabbak a Salvio nemorosae - Festucetum rupicolae Zólyomi ex Soó 1964, Agropyro cristati - Kochietum prostratae Zólyomi 1958; Achilleo setaceae - Festucetum pseudovinae Soó (1933) 1947 corr. Borhidi 1996 és az Artemisio santonici - Festucetum pseudovinae Soó in Máthé 1933 corr. Borhidi 1996 (Joó 2003, BEDE et al. 2014). A halmok számos ritka növényfaj számára nyújtanak élőhelyet, mint például a szikes gyepekre jellemző Bassia sedoides, Kochia prostrata, a löszgyepekre jellemző Festuca javorkae, Phlomis tuberosa, Thalictrum minus, Stipa capillata és kivételes esetekben árvalányhajas erdőspusztarét elemet is hordozhat, mint a Stipa tirsa, Echium maculatum vagy a Gentiana cruciata (Zólyomi 1969, Joó 2003, TAKÁCS et al. 2013, BEDE et al. 2014).

TóTH et al. (2014) szerint Magyarországon a történelmi időkben a kunhalmok száma elérhette a negyvenezret, napjainkra ez a szám nagyságrendekkel csökkent (TóTH et al. 2006, BEDE 2012). Megfogyatkozott számuk ellenére a halmok kultúrtörténeti és természetvédelmi jelentősége kiemelkedő (TóTH \& TóTH 2004, BEDE 2014). A kunhalmok természetvédelmi jelentőségét az is mutatja, hogy az intenzív művelésű agrárterületeken gyakran olyan értékes élőhelyek őrzői, mint a lösz- és szikes gyepek (DEÁK et al. 2014a, b, VALKó et al. 2014a).

\section{Anyag és módszer}

A kutatásunk során a Hencida község közigazgatási határában található Mondró-halom (N 47.222028 / E 21.738456 KEF: 8796.3) vegetációját vizsgáltuk (1. ábra). A bejárásokat 2014. május 8-án és szeptember 1-jén végeztük. A vizsgálat során feljegyeztük a halmon található gyepben előforduló edényes növényfajokat és azok összborítását. A fajnevek használata KIRÁLY (2009) nevezéktanát követi. A szárazgyepi karakterfajok, az erdőssztyeppi fajok, valamint a flórelemek besorolását HoRvÁTH et al. (1995) alapján végeztük. A gyepben öt ponton megmértük a növényzet magasságát, valamint a felhalmozódott avar vastagságát.

\section{Eredmények}

A halom alapterülete szabályos kör alakú, melynek átmérője 96 méter. A halom relatív magassága 7 méter. A halomtest viszonylag érintetlen, a tetején egy oszlopot és egy 
háromszögelési pontot találtunk. A halmot egy hozzávetőleg 1 méter mély árok és sűrű cserjesáv választja el a környező szántóterületektől. A halmon legeltetés vagy kaszálás nyomát nem észleltük.

A halmon négy vegetáció-típust találtunk: (1) a halom tetejét löszfalnövényzet (Agropyro cristati - Kochietum prostratae Zólyomi 1958); (2) a halom testet túlnyomórészt jó természetességű löszgyep (Salvio nemorosae - Festucetum rupicolae Zólyomi ex Soó 1964) borította; (3) a keleti és déli oldalán cserjefajok előretörése volt megfigyelhető; (4) az északi részen jellegtelen fás vegetációt találtunk.



1. ábra. A hencidai Mondró-halom déli oldala.

Előtérben a hengeresfészkű peremizs (Inula germanica) állományával (Deák B. felvétele).

Fig. 1. Southern slope of the Mondró-halom kurgan with the extended stand

of german inula (Inula germanica) in the foreground (Hencida, East-Hungary) (photo by B. Deák).

A gyep átlagos magassága az Agropyro cristati - Kochietum prostratae társulásban $37 \mathrm{~cm}$, a Salvio nemorosae - Festucetum rupicolae löszgyepben 56 centiméter volt, a felhalmozódott avar átlagos magassága 0,5 illetve $1,5 \mathrm{~cm}$, az avar átlagos borítása rendre $30 \%$, illetve $80 \%$ volt. A gyepben a cserjék borítása 14,2\% volt. A Mondró-halmon található 60×40 méteres gyepben összesen 74 edényes, ebből 69 lágyszárú növényfaj találtunk. Az alábbiakban közöljük a Mondró-halom gyeppel borított részén megtalált edényes növényfajok listáját, a fajnevek után megadva a fajok teljes gyepterületre vonatkoztatott százalékos borításértékeit. A szárazgyepi karakterfajokat (Festuco-Brometea) aláhúzással, az erdőssztyeppi fajokat csillaggal (*) jelöltük (HoRVÁTH et al. 1995). 
Achillea collina (0,1); Agropyron cristatum (0,3); Ajuga genevensis (0,3); Anthoxanthum odoratum (0,7); Asparagus officinalis (1); Aster sedifolius* (0,3); Betonica officinalis* (2); Bromus hordeaceus $(0,5)$; Bromus sterilis $(0,1)$; Calamagrostis epigeios (2); Capsella bursapastoris (0,1); Cardaria draba $(0,1)$; Carduus acanthoides $(0,5)$; Carex praecox $(0,1)$; Centaurea scabiosa (0,1); Cerastium brachypetalum $(0,1)$; Chenopodium album $(0,1)$; Crataegus monogyna $(0,1)$; Crepis tectorum $(0,1)$; Dactylis glomerata $(0,1)$; Descurainia sophia (0,3); Dianthus pontederae (0,1); Elymus hispidus (11); Eryngium campestre (0,3); Falcaria vulgaris (0,1); Fallopia convolvulus $(0,1)$; Festuca rupicola (15); Filipendula vulgaris $(0,7)$; Fragaria viridis $(0,3)$; Galium spurium $(0,1)$; Galium verum $(0,5)$; Geum urbanum $(2)$; Glechoma hederacea $(0,1)$; Hypericum perforatum $(0,3)$; Inula germanica (27); Kochia prostrata $(2,5)$; Koeleria cristata $(0,3)$; Lamium amplexicaule $(0,1)$; Lamium purpureum $(0,1)$; Lathyrus tuberosus $(0,1)$; Lychnis viscaria $(0,1)$; Medicago lupulina $(0,1)$; Medicago sativa $(0,1)$; Muscari comosa $(0,5)$; Myosotis stricta $(0,1)$; Ornithogalum umbellatum agg. $(0,1)$; Phragmites australis (0,5); Poa angustifolia (2); Potentilla argentea (0,1); Prunus spinosa (8); Pseudolysimachion spicatum (0,3); Ranunculus illyricus* $(0,1)$; Rosa canina (4); Rosa gallica* (2); Rumex patientia subsp. patientia $(0,5)$; Salvia pratensis $(0,5)$; Saxifraga bulbifera $(0,1)$; Seseli sp. (2); Stachys recta (0,3); Stellaria graminea (0,1); Teucrium chamaedrys* (18); Thalictrum minus* (1); Thesium linophyllon* $(0,5)$; Thymus glabrescens $(0,7)$; Trifolium alpestre $(0,1)$; Trifolium arvense $(0,1)$; Tripleurospermum perforatum $(0,1)$; Ulmus laevis $(0,1)$; Valerianella locusta $(0,1)$; Verbascum phoeniceum $(0,3)$; Veronica arvensis $(0,1)$; Vicia grandiflora $(0,3)$; Vicia hirsuta $(0,3)$; Viola kitaibeliana $(0,1)$.

A Mondró-halom területén három védett növényfaj volt jelen. A legnagyobb állománya a hengeresfészkű peremizsnek (Inula germanica) volt (2000 tő). A hengeresfészkű peremizs előfordulására történő hivatkozást Soó (1938) Bihari-síkról közölt flóraművében találtunk: a fajt STEFFEK (1864) és SimonKAI (1890) jelezte Nagyvárad közeléből. A Mondró-halomon talált további védett fajok a selymes boglárka (Ranunculus illyricus, 2 tő) és a réti őszirózsa (Aster sedifolius, 15 tő). Míg a selymes boglárkáról nem találtunk sem irodalmi sem herbáriumi adatot, a réti őszirózsa számos Biharban gyüjtött példánya van elhelyezve a Debreceni Egyetem TTK Növénytani Tanszék herbáriumában (TAKÁcs et al. 2014).

További érdekes florisztikai adat a heverő seprőfü (Kochia prostrata), taréjos búzafú (Agropyron cristatum), gumós kőtörőfü (Saxifraga bulbifera), bérci here (Trifolium alpestre), parlagi rózsa (Rosa gallica), enyves szurokszegfü (Lychnis viscaria) és a közönséges borkóró (Thalictrum minus) előfordulása. A Saxifraga bulbifera előfordulásáról a Bihari-síkon négy irodalmi adat tesz említést. Máthé Imre a hencidai Csere-erdőből (Soó \& MÁTHÉ 1938), SiMONKAI (1890) Biharszentandrásról, STEFFEK (1864) Nagyvárad környékéről írta le a fajt. A Debreceni Egyetem herbáriumában a faj két, a térségből származó példánya lett elhelyezve: Kovács L. gyújtése (1926) a hencidai Csere-erdőből, és Gulyás G. gyűjtése (2014) a konyári Angyalosi-mellékcsatorna melletti sziki erdőssztyeppről (TAKÁCs et al. 2014). A Rosa gallica egyetlen Biharból származó adatát a Debreceni Egyetem herbáriumában találtuk meg (Berettyóújfalu, 2011, Molnár V. et al.). A Lychnis viscaria bihari előfordulásáról SimonKAI (1890) és STEFFEK (1864) tesz említést Nagyvárad közeléből. Máthé Imre a hencidai Csereerdőből írta le a fajt (Soó \& Máthé 1938). A Debreceni Egyetem herbáriumában a faj két példánya van elhelyezve: KovÁcs L. 1936-os gyűjtése a hencidai Csere-erdőből és egy ismeretlen gyüjtő adata Sárándról (TAKÁCS et al. 2014).

A cserjésedő rész hozzávetőlegesen a halom 30\%-át borította. Főként kökény, egybibés galagonya és fekete bodza magas borítása jellemezte, a zárt cserjeborítás alatt a lágyszárú szint jelentősen visszaszorult. Érdekes módon a cserjék alatt nagyobb borítással volt jelen két olyan faj, amelyek a térségben ritkák és mezofil élőhelyekre jellemzők (Saxifraga bulbifera és Betonica officinalis). Ennek oka valószínűleg a cserjék által biztosított hűvösebb 
és nedvesebb mikroklíma. A fás vegetációban, ami a halom $10 \%$-át borította, elsősorban a szürke nyár, fehér akác és mezei juhar dominált, a cserjeszintben pedig a kökény, egybibés galagonya és fekete bodza. Az aljnövényzet többnyire jellegtelen volt, viszont említésre érdemes a Ranunculus ficaria előfordulása.

\section{Eredmények értékelése}

A Mondró-halmon táji szinten is igen jó állapotú löszgyep őrződött meg, annak ellenére, hogy az I-III. katonai felmérések alapján a halom környezetére a 18. századtól kezdve a szántóföldi gazdálkodás volt jellemző. Ez valószínűleg annak köszönhető, hogy a halom oldala igen meredek, így beszántása nem volt lehetséges. Jelenleg a halmot egy igen mély árok és többé-kevésbé áthatolhatatlan cserjesáv veszi körül, ami szintén hozzájárul a halmon található löszgyep fennmaradásához, mert jelentősen nehezíti a halom esetleges szántóföldi művelését.

A halom refúgiumként szolgál a löszvegetáció számára, ami kis kiterjedésben, de igen nagy fajgazdagságban maradt fenn napjainkig. A kunhalmok refúgium szerepe igen jelentős a Bihari-síkon, ahol a jó termőképességű talajokon a löszgyepi vegetáció termőhelyeinek jelentôs részét már évszázadok óta művelésbe vonták, így az értékes fajgazdag gyepek területe jelentősen csökkent. Bár tapasztalataink alapján a térségben a Mondró-halom az egyik legjobb természetességú és emellett kiemelkedően fajgazdag kunhalom, több olyan halom (Inacs-halom, Hegyes-halom, Erdő-halom, Béka-halom, Ebéd-halom, Makkosi-halom, Róka-halom, Kornyó-halom és Török-halom) is található a Bihari-síkon, amely jó állapotú löszgyepi vegetációt hordoz.

A halom speciális helyzete, meredeksége és viszonylagos háborítatlansága miatt kiemelkedően változatos a növényzet flóraelem-összetétele. Az általunk vizsgált egy hektárnál is kisebb gyepfragmentumon a legtöbb a kárpát-medencei sztyeppei flóraelemtípus (kontinentális, pontusz-szubmediterrán, pontuszi, pontusz-pannon és turáni) megtalálható. Emellett a halmon számos erdőssztyeppfaj is előfordul.

A kunhalmoknak a fragmentált kultúrtájakban nagy szerepük van az eredeti növényzet és a kistájra jellemző növényközösségek és ritka fajok megőrzésében, amely különösen igaz a hencidai Mondró-halom esetében. A kunhalmok természetvédelmi szempontból kiemelt figyelmet érdemelnek, mert a rajtuk található általában kis kiterjedésű gyep-fragmentumok igen sérülékenyek, számos esetben fenyegeti őket a beszántás, beépítés vagy az erdősítés (BEDE 2014, TóTH \& TóTH 2004). A bejárás tanulsága alapján a halmon található vegetáció megőrzése rövid távon biztosított, azonban a jövőben számos, a kezelés elmaradásával járó negatív hatásra lehet számítani, mint például a fásszárú fajok valamint a terresztris nád előretörése, avarfelhalmozódás és a kistermetű fajok visszaszorulása. A fajgazdag löszgyepi élőhely fennmaradása érdekében a jövőben mindenképpen szükség lehet természetvédelmi célú beavatkozásokra, mint a néhány évenkénti kézi kaszálásra és a részleges cserjeirtásra (DEÁK \& TóthmérésZ 2006, VALKó et al. 2011, VALKó et al. 2012, VALKó et al. 2014b, KELEMEN et al. 2014, MolNÁR et al. 2014).

\section{Köszönetnyilvánítás}

A szerzők köszönik Takács Attilának a Debreceni Egyetem herbáriumi adatainak kigyüjtésében nyújtott segítségét. Hálásak vagyunk Csathó András Istvánnak és Tóth Csabának a bírálat során nyújtott hasznos tanácsaiért és észrevételeiért. A szerzőket a kézirat elkészítése során az OTKA PD 100192 és PD 111807 sz. pályázatai támogatták. 


\section{Irodalomjegyzék}

BEDE Á. (2012): Beszámoló a Békés megyei Kis-Sárrét halmainak felméréséről. - In: KISFALUdI J. (szerk.), Régészeti kutatások Magyarországon 2010. - Kulturális Örökségvédelmi Hivatal - Magyar Nemzeti Múzeum, Budapest, pp. 55-73.

BEDE Á. (2014): Beszámoló a Békés megyei Nagy-Sárrét halmainak felméréséről. - Crisicum 8: 17-43.

Bede Á., Csathó A. I., Czukor P., PÁll D. G., Szilágyi G. \& Sümegi P. (2014): A hortobágyi Ecse-halom geomorfológiai, tájtörténeti, botanikai, szedimentológiai és mikromorfológiai vizsgálatának előzetes eredményei. - In: SÜMEGI P. (szerk.), Környezetföldtani és környezettörténeti kutatások a dunai Alföldön. - GeoLitera - SZTE TTIK Földrajzi és Földtani Tanszékcsoport, Szeged, pp. 29-41.

CsATHó A. I. (2009): A mezsgyék természetvédelmi jelentősége és védelmük időszerűsége. Természetvédelmi Közlemények 15: 171-181.

Csathó A. I., Bede Á., Sudnik-Wójcikowska, B., Moysiyenko, I., Dembicz, I. \& Sallainé Kapocsi J. (2015): A szagtalan rezeda (Reseda inodora Rchb.) előfordulása a Tiszántúlon. - Kitaibelia 20: 48-54.

DANI J. \& HoRváth T. (2012): Öskori kurgánok a magyar Alföldön. A Gödörsíros (Jamnaja) entitás magyarországi kutatása az elmúlt 30 év során. Áttekintés és revízió. - Archaeolingua Alapítvány, Budapest, $215 \mathrm{pp}$.

DEÁK B. \& TóTHмÉRÉSz B. (2006): Kaszálás hatása a növényzetre a Nyírőlapos (Hortobágy) három növénytársulásában. - In: MoLNÁR E. (szerk.), Kutatás, oktatás, értékteremtés. MTA ÖBKI, Vácrátót, pp. 169-180.

DeÁK B., VAlKó O., TöRÖK P. \& TóthméRÉSZ B. (2014a): Solonetz meadow vegetation (Beckmannion eruciformis) in East-Hungary - an alliance driven by moisture and salinity. - Tuexenia 34: 187-203.

DeÁk B., ValKó O., AleXander C., MüCKe W., Kania A., TAMÁs J. \& Heilmeier H. (2014b): Fine-scale vertical position as an indicator of vegetation in alkali grasslands - case study based on remotely sensed data. - Flora 209: 693-697.

Dengler, J., JAnıšovÁ, M., TöRöK P. \& Wellstein, C. (2014): Biodiversity of Palaearctic grasslands: a synthesis. - Agriculture, Ecosystems \& Environment 182: 1-14.

Horváth F., Dobolyi K., MorschHauser T., LőKös L., Karas L. \& SZERdahelyi T. (1995): Flóra adatbázis 1.2. Taxon-lista és attributum állomány. - MTA ÖBKI, Vácrátót, 267 pp.

Joó K. (2003): Kunhalomkutatások (A Csípő-halom vegetációja). - Tájökológiai Lapok 1: 87-96.

Kelemen A., TöröK P., Deák B., VAlKó O., LuKács B. A., Lengyel Sz. \& TóthméréSz B. (2010): Spontán gyepregeneráció extenzíven kezelt lucernásokban. - Tájökológiai Lapok 8: 33-44.

Kelemen A., TöröK P., ValKó O., DeÁK B., Miglécz T., Tóth K., Ölvedi T. \& Tóthmérész B. (2014): Sustaining recovered grasslands is not likely without proper management: vegetation changes and large-scale evidences after cessation of mowing. - Biodiversity \& Conservation 23: 741-751.

KIRÁLY G. (szerk.) (2009): Új magyar füvészkönyv. Magyarország hajtásos növényei. Határozókulcsok. Aggteleki Nemzeti Park Igazgatóság, Jósvafő, 616 pp.

Molnár Zs., Horváth A., Csathó A. I., LendVAi G. \& BARTHA S. (2014): 6250 Síksági pannon löszsztyeppek. - In: Haraszthy L. (szerk.), Natura 2000 fajok és élőhelyek Magyarországon. - Pro Vértes Közalapítvány, Csákvár, pp. 810-816.

Penksza K., Kiss T., Herczeg E., Nagy A. \& Malatinszky Á. (2011): Anthropogenic impacts and management of natural grasslands on kurgans. - In: PETó Á. \& BARCZı A. (szerk.), Kurgan studies: An environmental and archaeological multiproxy study of burial mounds in the Eurasian steppe zone. - BAR International Series. Oxford, pp. 329-338.

Simonkai L. (1890): Nagyvárad és vidéke növényvilága. - In: BunYITAY V. (szerk.), Nagyvárad természetrajza. pp. 47-137.

Soó R. \& Máthé I. (1938): A Tiszántúl flórája. - Institutio Botanici Universitatis Debreceniensis, Debrecen, $192 \mathrm{pp}$.

StefFeK, A. (1864): Übersicht der bei Grosswardein bis jetzt beobachteten Phanerogamen. Österreichische Botanische Zeitshrift. 14: 169-187.

Sudnik-Wójcikowska, B. \& Moysiyenko, I. I. (2008): The floristic differentiation of Microhabitats within Kurgans in the desert steppe zone of Southern Ukraine. - Acta Societas Botanicorum Poloniae 77: 139-147. 
SUdNiK-WójcikowsKa, B., MoYsiYenKo, I. I., ZACHWATOWICZ, M. \& JABŁoŃSKA, E. (2011): The value and need for protection of kurgan flora in the anthropogenic landscape of steppe zone in Ukraine. - Plant Biosystems 145: 638-653.

Takács A., Nagy T., Fekete R., Lovas-Kiss Á., Ljubka T., LöKi V., LisZTes-Szabó Zs. \& Molnár V. A. (2014): A Debreceni Egyetem Herbáriuma (DE) I.: A „Soó Rezső Herbárium”. - Kitaibelia 19: 142-155.

TAKÁCS A., SCHMOTZER A. \& SulYOK J. (2013): Florisztikai adatok a Sajó-Hernád-sík területéről. - Kitaibelia 18: 73-88.

Tóтн A. \& Tóтн Cs. (2004): A kunhalom-program általános tapasztalatai. - In: Tóth A. (szerk.), A kunhalmokról - más szemmel. Kisújszállás - Debrecen, pp. 171-180.

TóTH Cs. (2006): Az országos kunhalomfelmérés eredményei a földtani értékvédelem szemszögéből. Geology, Geomorphology, Physical Geography 1: 129-135.

Tóth Cs., Pethe M. \& HATHÁzi Á. (2014): The application of earth science-based analyses on a twinkurgan in Northern Hungary. - Carpathian Journal of Earth and Environmental Sciences 9: 19-20.

TótH K. \& HüSE B. (2014): Soil seed banks in loess grasslands and their role in grassland recovery. Applied Ecology and Environmental Research 12: 537-547.

Valkó O., Tóthmérész B., Kelemen A., Simon E., Miglécz T., LuKÁcs B. \& TöRöK P. (2014a): Environmental factors driving vegetation and seed bank diversity in alkali grasslands. - Agriculture, Ecosystems \& Environment 182: 80-87.

VAlKó O., TöRöK P., DEÁK B. \& TóthmÉRÉSZ B. (2014b): Prospects and limitations of prescribed burning as a management tool in European grasslands. - Basic and Applied Ecology 15: 26-33.

VALKó O., TÖRÖK P., MATUS G. \& TóTHMÉRÉSZ B. (2012): Is regular mowing the most appropriate and costeffective management maintaining diversity and biomass of target forbs in mountain hay meadows? - Flora 207: 303-309.

VALKó O., TöRÖK P., TóthméRÉSz B. \& Matus G. (2011): Restoration potential in seed banks of acidic fen and dry-mesophilous meadows: Can restoration be based on local seed banks? - Restoration Ecology 19: 9-15.

Vona M. \& PEnKsza K. (2004): A szentesi Kántor-halom vegetációjának változása és ennek összefüggése a talaj vízháztartásával. - Tájökológiai Lapok 2: 341-348.

ZóLYOMı B. (1969): Földvárak, sáncok, határmezsgyék és a természetvédelem. - Természet Világa 100 : 550-553.

Beérkezett / received: 2015. 01. 28. • Elfogadva / accepted: 2015. 02. 18. 